\title{
Studi kasus manajemen asuhan kebidanan ibu hamil pada Ny. W dengan tuberkulosis paru di poli obsgyn RSUD Dr. Adyatma. MPH Semarang
}

\author{
Nurul Innayah ${ }^{1}$ \\ ${ }^{1}$ Universitas Negeri Semarang
}

\begin{tabular}{l}
\hline INFORMASI ARTIKEL: \\
\hline Riwayat Artikel: \\
Tanggal diterima: 18 April 2021 \\
Tanggal direvisi: 26 Juni 2021 \\
Tanggal dipublikasi: 26 Juli 2021 \\
\hline
\end{tabular}

Kata kunci:

Manajemen Asuhan Kebidanan

Tuberculosis Paru

\subsection{6/jrki.v5i1.157}

Keyword:

Midwifery Care Management

Pulmonary Tuberculosis

\begin{abstract}
ABSTRAK
Latar belakang: Infeksi pada kehamilan menduduki peringkat ke-3 $(2,76 \%)$ penyebab kematian ibu di Provinsi Jawa Tengah. Tuberculosis adalah salah satu infeksi yang terjadi pada ibu hamil. Tuberculosis pada kehamilan dapat menimbulkan komplikasi diantaranya Intrauterine Growth Retardation (IUGR), berat badan lahir rendah perinatal dan keparahan lesi di paru maupun infeksi ekstrapulmoner akibat pengobatan yang tidak teratur. Tujuan penelitian: Untuk memperoleh gambaran umum pelaksanaan asuhan kebidanan pada ibu hamil dengan Tuberculosis Paru di RSUD Dr. Adyatma, MPH Semarang. Metode: Jenis penelitian bersifat deskriptif menggunakan pendekatan studi kasus Manajemen Kebidanan yang terdiri dari tujuh langkah Varney yaitu: Pengumpulan Data, Interpretasi Data, Identifikasi Diagnosa atau Masalah Potensial, Kebutuhan Tindakan Segera, Rencana Asuhan dan Pelaksanaan Asuhan, serta pendokumentasian dengan metode SOAP. Hasil: Hasil dari tindakan sudah teratasi dengan baik, terbukti saat pertama kali datang Ny. W dengan keluhan batuk-batuk tidak kunjung sembuh selama 3 minggu, tidak enak badan, nafsu makan menurun dan demam pada pengkajian ketiga Ny. W mengatakan batuknya membaik, nafsu makan sudah membaik. Ibu dapat menjalani kehamilan dengan normal. Simpulan: Penerapan asuhan kebidanan pada Ny. W dengan Tuberculosis Paru telah sesuai dengan tujuh Langkah Varney meskipun terdapat beberapa kesenjangan antara praktik di lahan dan teori.
\end{abstract}

Background: Infections in pregnancy ranked 3rd (2.76\%) maternal cause of death in Central Java Province. Tuberculosis is one of the infections that occurs in pregnant women. Tuberculosis in pregnancy can lead to complications such as Intrauterine Growth Retardation (IUGR), low perinatal birth weight and severity of lesions in the lungs as well as extrapulmonary infections due to irregular treatment. Objective: To get an overview of the implementation of midwifery care in pregnant women with Pulmonary Tuberculosis at Dr.Adyatma Hospital,MPH Semarang. Methods: This type of research is descriptive using the case study approach of Midwifery Management consisting of seven steps varney namely: Data Collection, Data Interpretation, Identification of Diagnosis or Potential Problems, Need for Immediate Action, Foster Care Plan and Implementation of Care, and documentation with SOAP method. Results: The results of the action have been well resolved, proven when mrs. W first came with complaints of coughing did not heal for 3 weeks, unwell, decreased appetite and fever in the third study Mrs. W said her cough improved, appetite had improved. Mothers can have a normal pregnancy. Conclusion: The application of midwifery care to Mrs $W$ with Pulmonary Tuberculosis has been appropriate in Varney's seven steps although there are some gaps between land practice and theory.

pembangunan nasional. Tujuan MDGs salah satunya adalah meningkatkan kesehatan ibu. Menurut laporan dari kabupaten/ kota Angka Kematian Ibu (AKI) Provinsi Jawa Tengah tahun 2015 sebesar 111,16/100.000 kh, terjadi penurunan tahun 2014 sebesar 126,52/100.000 kh. Berdasarkan target Millenium Development Goals (MDGs) pada tahun 2015 yang telah diganti

\footnotetext{
Korespondensi penulis.

Alamat E-mail: anonim@mail.com
}

negara yang ikut MDGs, Indonesia mempunyai komitmen untuk melakukan program 
dengan Sustainable Development Goals (SDGs) AKI hanya di targetkan kurang dari 70 per $100.000 \mathrm{kh}$ pada tahun 2030. Dengan target ini pemerintah Indonesia akan sulit memenuhi target SDGs (Dinas Kesehatan Provinsi Jawa Tengah, 2015).

Sebesar 60,90\% kematian maternal terjadi pada waktu nifas, pada waktu hamil sebesar 26,33\% dan pada waktu persalinan sebesar $12,76 \%$. Untuk penyebab kematian bisa dari infeksi sebesar 2,76\% (Dinas Kesehatan Provinsi Jawa Tengah, 2015). Infeksi menduduki peringkat ke-3 penyebab kematian ibu di Provinsi Jawa Tengah. Penyakit infeksi yang sering terjadi pada ibu hamil antara lain Toxoplasma, Rubella, Cytomegalovirus, Herpes (TORCH), Hepatitis, Tuberkulosis, Human Immuno Deficiency Virus/ Acquired Immuno Deficiency Syndrome (HIV/AIDS), dan lain-lain. Insiden Tuberkulosis tampaknya dipengaruhi oleh lokasi geografi dan status sosial ekonomi pada populasi tertentu. Pada wanita usia subur, tuberkulosis masih merupakan salah satu penyakit infeksi yang umum ditemukan (Varney, 2007).

Tuberkulosis (TB) disebabkan oleh basil tuberkel, Mycobacterium Tuberculosis (Fraser, 2009). Tuberkulosis pada kehamilan tidak banyak memberikan pengaruh terhadap cepatnya perjalanan penyakit ini, banyak penderita tidak mengeluh sama sekali. Penyakit ini mungkin bentuknya aktif atau kronik, dan mungkin pula tertutup atau terbuka (Marmi, 2011).

Komplikasi yang ditimbulkan dari TB paru pada kehamilan antara lain risiko prematuritas, Intrauterine Growth Retardation (IUGR) dan berat badan lahir rendah perinatal. Dapat terjadi keparahan lesi di paru maupun infeksi ekstrapulmoner akibat pengobatan yang tidak teratur (Prawirohardjo, 2009).

Case Notification Rate (CNR) untuk semua kasus TB di Jawa Tengah tahun 2015 sebesar $117,36 / 100.000$ peduduk, hal ini menunjukkan kasus Tuberkulosis di Jawa Tengah mengalami peningkatan dibandingkan tahun 2014 yaitu $89,01 / 100.000$ penduduk. Untuk daerah Kabupaten Semarang sebanyak 74,6/100.000 penduduk (Dinas Kesehatan Provinsi Jawa Tengah, 2015).

Di Poli Obsgyn RSUD Dr. Adhyatma. MPH Semarang data kunjungan ibu hamil pada tahun 2015 adalah 7941 ibu hamil sedangkan pada tahun 2016 selama bulan Januari sampai April sebanyak
3035 ibu hamil. Untuk kasus ibu hamil dengan Tuberkulosis Paru pada tahun 2015 adalah 5 kasus rawat jalan sedangkan pada tahun 2016 selama bulan Januari sampai April sebanyak 2 kasus rawat jalan. Berdasarkan hasil wawancara dengan Bidan dan Dokter Obgyn di Poli Obsgyn RSUD Dr. Adhyatma, MpH Semarang ibu hamil dengan TB Paru biasanya sudah rujukan dari puskesmas atau bidan setempat yang akan diperiksa ulang dahak sewaktu-pagi-sewaktu (SPS) dalam dua hari, setelah didapatkan dahak SPS, dahak di periksa oleh laboratorium dan di dapatkan hasil dahak negative/ positif di dukung dengan rontgen paru dari radiologi serta kolaborasi dengan dokter obsgyn dan dokter spesialis paru. Untuk penanganannya ibu hamil dengan TB Paru akan diberikan obat anti tuberkulosis (OAT) sesuai dengan klasifikasinya, dan ibu hamil dianjurkan untuk kontrol ulang paling tidak dua minggu sekali pada pengobatan awal dan saat OAT habis. Satu bulan sebelum pengobatan ibu hamil dengan TB Paru berakhir akan diperiksa kembali dahaknya untuk mengetahui hasil pengobatan (Data Rekam Medik RSUD Dr. Adhyatma, MpH Semarang).

\section{Metode penelitian}

Metode yang digunakan dalam penelitian ini adalah deskriptif observasional pendekatan studi kasus dengan penerapan Manajemen Asuhan Kebidanan Tujuh Langkah Varney dan pendokumentasian metode SOAP. Populasi penelitian adalah seluruh ibu hamil dengan Tuberkulosis Paru di Poli Obsgyn RSUD Dr. Adhyatma, $\mathrm{MpH}$ Semarang. Subjek penelitian adalah seorang ibu hamil dengan Tuberkulosis Paru di Poli Obsgyn RSUD Dr. Adhyatma, $\mathrm{MpH}$ Semarang. Data primer yang diperoleh dari hasil penelitian dengan cara anamnesa, pemeriksaan, observasi dan dokumentasi menggunakan format pengkajian kehamilan normal. Analisa data dengan membandingkan antara data yang diperoleh dengan teori yang ada sesuai 7 langkah Varney.

\section{Hasil dan Pembahasan}

Pengkajian I Selasa, 26 April 2016, pukul 10.40 WIB, tempat Poli Obgyn RSUD Dr. Adhyatma, MpH Semarang

\section{Data Umum}

Nama Ibu: Ny.W, Umur: 35 tahun, Agama: Islam, Suku/Bangsa: Jawa/Indonesia, Pendidikan terakhir: SMP, Pekerjaan: IRT, Alamat: Mangkang 
Wetan RT 02 RW 01 Kota Semarang. Dan suaminya bernama Tn. J berusia 37 tahun.

\section{Data Subyektif}

Ibu datang mengatakan ingin memeriksakan keadaannya dan janinnya atas anjuran bidan dengan keluhan utama batuk-batuk tidak kunjung sembuh selama 3 minggu, tidak enak badan, nafsu makan menurun, demam dan ibu merasa cemas. Riwayat kesehatan dahulu dan sekarang tidak pernah menderita penyakit menular, menahun dan menurun. Riwayat keluarga ibu mengatakan suaminya baru beberapa bulan yang lalu menderita penyakit TBC.

Riwayat obstetri ibu adalah menarche: 13 tahun, siklus haid: 28 hari, lama haid: 6-7 hari, karakteristik: cair, kadang bergumpal, berwarna merah kecoklatan, ganti pembalut 3-4x/ hari, HPHT: 10 Oktober 2015 dan HPL: 17 Juli 2016.

Tabel 1 Riwayat Kehamilan, Persalinan \& Nifas yang Lalu

\begin{tabular}{|c|c|c|c|c|c|c|c|c|}
\hline $\begin{array}{l}\text { Ana } \\
\text { k } \\
\text { ke }\end{array}$ & $\begin{array}{l}\text { Um } \\
\text { ur } \\
\text { Ana } \\
k\end{array}$ & UK & $\begin{array}{l}\text { Jenis } \\
\text { Partus }\end{array}$ & $\begin{array}{l}\text { Temp } \\
\text { at } \\
\text { Partu } \\
\text { s }\end{array}$ & $\mathrm{BBL}$ & $\begin{array}{l}\mathrm{L} \\
/ \\
\mathrm{P}\end{array}$ & Nifas & Ket \\
\hline 1 & $\begin{array}{l}13 \\
\text { th }\end{array}$ & $\begin{array}{l}39 m \\
g g\end{array}$ & $\begin{array}{l}\text { Norm } \\
\text { al }\end{array}$ & $\mathrm{RS}$ & $\begin{array}{l}325 \\
0 \\
\end{array}$ & $P$ & $\begin{array}{l}\text { Norm } \\
\text { al }\end{array}$ & Sehat \\
\hline 2 & 8 th & $\begin{array}{l}40 m \\
g g\end{array}$ & $\begin{array}{l}\text { Norm } \\
\text { al }\end{array}$ & RS & $\begin{array}{l}360 \\
0 \\
\end{array}$ & $\mathrm{~L}$ & $\begin{array}{l}\text { Norm } \\
\text { al }\end{array}$ & Sehat \\
\hline 3 & - & $\begin{array}{l}12 \mathrm{~m} \\
\mathrm{gg}\end{array}$ & $\begin{array}{l}\text { Kureta } \\
\text { se }\end{array}$ & $\mathrm{RS}$ & - & - & - & $\begin{array}{l}\text { Abort } \\
\text { us }\end{array}$ \\
\hline 4 & Ham & & & & & & & \\
\hline
\end{tabular}

Imunisasi TT $1 x$, tablet Fe 1x/hari, usia kehamilan sekarang adalah 7 bulan, ibu mengatakan merasakan gerakan janin sejak UK 5 bulan sampai sekarang, ibu merasakan gerakan janin $\pm 10 x /$ hari. Ibu hanya mengkonsumsi obat yang diberikan bidan. Keluhan selama hamil Trimester I mual dan muntah, Trimester II nyeri perut dan Trimester III batuk-batuk.

Pola kehidupan sehari-hari ibu mengalami penurunan nafsu makan dibandingkan sebelum hamil. Ibu mengatakan tinggal di tempat yang bersih, bangungan permanen, lantai rumah kramik dan terdapat jendela di setiap ruangan rumahnya. Ibu mengatakan sudah mengetahui cara penularan penyakit TBC yaitu dengan terpapar langsung dengan penderita namun ibu belum mengetahui cara batuk yang benar agar tidak tertular ke anggota keluarga yang lain.

\section{Data Obyektif}

Pemeriksaan Fisik Ny. W adalah:

Keadaan umum: baik, kesadaran: composmentis, BB saat hamil: $56 \mathrm{~kg}$, BB sebelum hamil: $49 \mathrm{~kg}$, TB: $155 \mathrm{~cm}$, Lila: $23 \mathrm{~cm}$, TD: 110/80 $\mathrm{mmHg}$, Nadi: $94 \mathrm{x} /$ menit, RR: $28 \mathrm{x} /$ menit, Suhu: $37,2^{\circ} \mathrm{C}$. Muka sedikit pucat, terdapat retraksi dinding dada, terdapat bunyi ronkhi.

Pemeriksaan Obstetri:

Leopold I: TFU 3 jari diatas pusat, bagian perut teratas ibu teraba bulat lunak yaitu bokong janin. Leopold II: Bagian kanan teraba kecil-kecil yaitu ekstremitas janin. Bagian kiri teraba tahanan memanjang keras yaitu punggung janin. Leopold III: Teraba bulat keras yaitu kepala janin. Leopold IV: Belum masuk PAP. Panjang Uterus: $25 \mathrm{~cm}$. TBJ: 2015 gram. DJJ: 138x/ menit, terdengar kuat dan irama teratur. Punctum maksimum: Pertengahan antara pusat dan simpisis sebelah kiri. Pemeriksaan Penunjang Tes Hb 11,2 gr\%.

\section{Interpretasi Data}

Diagnosa Kebidanan: Ny.W umur 35 tahun G4P2A1 usia kehamilan 28 minggu 2 hari janin tunggal hidup intra uteri pungung kiri presentasi kepala konvergen dengan suspek TB paru.

\section{Identifikasi Diagnosa atau Masalah Potensial}

Tuberculosis Ekstra Paru, prematuritas, Intrauterine Growth Retardation (IUGR), dan berat badan lahir rendah.

\section{Kebutuhan Tindakan Segera}

Kolaborasi dengan dokter spesialis kandungan, dokter spesialis paru, petugas laboratorium dan radiologi.

\section{Rencana Asuhan, 26 April 2016 Pukul 10.50 WIB}

Jelaskan hasil pemeriksaan pada ibu dan keluarga. Beritahu ibu untuk menjaga pola makan. Jelaskan pendidikan kesehatan pencegahan penularan penyakit TB paru. Anjurkan ibu tetap mengkonsumsi obat dari bidan. Kolaborasi dengan dokter spesialis kandungan dengan advis: Dokter mengatakan perlu pemeriksaan 3 sampel dahak oleh laboratorium, ibu harus mengumpulkan dahak sewaktu, dahak pagi dan dahak sewaktu. Kolaborasi dengan dokter spesialis kandungan dengan advis: Anjurkan ibu besok datang ke poli paru menyerahkan pot yang sudah berisi dahak. 
6. Pelaksanaan Asuhan

1) Menjelaskan hasil pemeriksaan pada ibu dan keluarga bahwa ibu dalam keadaan kurang baik ditandai dengan suhu dan respirasi ibu di atas normal.

2) Memberitahu ibu untuk menjaga pola makan dengan makan sedikit-sedikit tapi sering agar berat badan bertambah dan makan makanan yang mengandung karbohidrat tinggi misalnya nasi, roti, ubi, olahan tepung serta protein tinggi seperti kacang-kacangan, tempe, keju, daging sapi, ayam, ikan dan telur.

3) Menjelaskan pendidikan kesehatan pencegahan penularan penyakit TB paru yaitu selalu menggunakan masker, apabila tidur usahakan tidak sekamar dengan anggota keluarga lainnya, sering berjemur di bawah sinar matahari saat di pagi hari, menjaga ruangan di dalam rumah dengan sering membuka jendela dan pintu agar sinar matahari bisa masuk, pertukaran udara yang lancar dan tidak lembab. Jika batuk harus ditutupi dengan sapu tangan atau tisu, jangan meludah sembarangan agar kuman TB tidak mudah tertular.

4) Menganjurkan ibu untuk tetap mengkonsumsi obat dari bidan yaitu tablet Fe $1 \times 1(60 \mathrm{mg})$ pada malam hari dan vitamin B6 $1 \times 1(25 \mathrm{mg})$ pada pagi hari untuk perkembangan janin.

5) Kolaborasi dengan dokter spesialis dokter kandungan dengan advis perlu dilakukan pemeriksaan 3 sampel dahak oleh laboratorium yaitu sewaktu ibu periksa pertama kali tgl 26 April 2016 dahak dikeluarkan dalam pot kecil untuk tempat dahak, saat ibu pulang akan diberikan pot kecil untuk besok pagi tgl 27 April 2016 saat bangun tidur dahak dikeluarkan dalam pot kecil yang sudah diberikan oleh bidan, dan sewaktu menyerahkan pot dahak pagi ke Rumah Sakit ibu diminta mengeluarkan dahak lagi ke dalam pot kecil di rumah sakit.

6) Kolaborasi dengan dokter spesialis kandungan dengan advis: Menganjurkan ibu untuk besok datang ke poli paru menyerahkan pot yang sudah berisi dahak agar ibu mendapatkan penanganan dari dokter spesialis paru yang menangani penyakit tuberculosis.

\section{Evaluasi}

1) Ibu tahu hasil pemeriksaan dan merasa cemas.

2) Ibu bersedia menjaga pola makan dengan makan sedikit-sedikit tapi sering dan memperbanyak makanan yang mengandung karbohidrat tinggi dan protein tinggi.

3) Ibu paham dengan pencegahan penyakit tuberculosis agar tidak menular ke anggota keluarga lainnya.

4) Ibu bersedia tetap mengkonsumsi obat dari bidan.

5) Ibu bersedia di priksa 3 sampel dahak yaitu sewaktu datang pertama kali ke rumah sakit, sewaktu bangun pagi hari dan sewaktu menyerahkan dahak ke rumah sakit. Dan sudah didapatkan untuk sampel dahak pertama pada tanggal 26 April 2016 pukul 12.00 WIB hasil BTA-nya (+).

6) Ibu bersedia besok datang menyerahkan dahak pagi ke poli paru.

Pengkajian II Rabu, 27 April 2016, pukul 08.10 WIB, tempat Poli Paru

\section{Data Subyektif}

Ibu datang menyerahkan dahak pagi atas anjuran dokter kandungan kemarin. Keluhan: masih batuk-batuk seperti kemarin

\section{Data Obyektif}

KU: baik, kesadaran: composmentis, TD: 110/80mmHg, Nadi: 95x/menit, RR: 28x/menit, Suhu: $37,5 \circ C$. Muka sedikit pucat, ada retraksi dinding dada dan terdapat bunyi ronkhi. Tes laboratorium hasil BTA sewaktu (+).

\section{Assesment}

Ny.W umur 35 tahun G4P2A1 umur kehamilan 28 minggu 3 hari, janin tunggal hidup intra uteri preskep puki konvergen dengan suspek Tuberculosis Paru.

\section{Planning}

a) Kolaborasi dengan dokter spesialis paru mengenai hasil pemeriksaan bahwa keadaan ibu kurang baik ditandai dengan suhu dan respirasi diatas normal. (Ibu dan keluarga mengerti dengan hasil pemeriksaan dan merasa cemas).

b) Kolaborasi dengan dokter spesialis paru dengan advis agar ibu mengumpulkan sampel dahak ketiga kedalam pot kecil. (Ibu bersedia mengumpulkan sampel dahak ketiga kedalam pot kecil yaitu sewaktu datang ke RS).

c) Kolaborasi dengan dokter spesialis paru dengan advis agar ibu menyerahkan sampel dahak pagi dan sampel dahak yang ketiga ke ruang laboratorium untuk diperiksa. (Ibu 
bersedia menyerahkan sampel dahak ke ruang laboratorium dan hasil laboratorium keluar pada tanggal 27 April 2016 pukul 11.15 WIB hasil BTA pagi (+) dan hasil BTA sewaktu (-).

d) Kolaborasi dengan dokter spesialis paru dengan advis ibu perlu dilakukan pemeriksaan foto toraks oleh radiologi untuk menguatkan diagnosa penyakit tuberculosis. (Ibu bersedia dilakukan pemeriksaan radiologi dan hasil rontgen keluar pada tanggal 27 April 2016 pukul 11.45 WIB bahwa pada foto torak ibu nampak flek-flek pada paru).

e) Beritahu ibu untuk membawa hasil laboratorium dan hasil rontgen ke poli paru agar diserahkan ke dokter spesialis paru untuk penanganan lebih lanjut. (Ibu bersedia menyerahkan hasil laboratorium dan hasil rontgen ke dokter spesialis paru, dan dokter spesialis paru mengatakan bahwa ibu menderita penyakit tuberculosis paru dengan bukti bahwa hasil BTA (+) dan hasil foto torak nampak flek-flek pada paru).

f) Kolaborasi dengan dokter spesialis paru untuk informasi terapi obat anti tuberkulosis agar ibu dan keluarga paham, bahwa pengobatan OAT terdiri dari 2 tahapan pengobatan yaitu 2 bulan dan 4 bulan. Pada pengobatan 2 bulan obat yang dikonsumsi blister berwarna merah dan yang 4 bulan blister berwarna kuning. Pada blister berwarna merah mengandung rifampisin (150mg), isoniazid (75mg), pirazinamid (400mg), dan etambutol ( $275 \mathrm{mg})$. Ibu nanti akan diberikan 1 blister berwarna untuk 7 hari. Pengobatan tuberculosis ini harus rutin diminum setiap hari tidak boleh dilewatkan meskipun hanya 1 kaplet saja. (Ibu dan keluarga paham dengan pengobatan anti tuberculosis).

g) Kolaborasi dengan dokter spesialis paru mengenai cara minum OAT, yaitu ibu minum 4 kaplet sekali minum dalam sehari dengan air putih, sebaiknya diminum sebelum tidur kurang lebih jarak 2 jam setelah atau sebelum minum tablet tambah darah. (Ibu dan keluarga paham mengenai cara minum OAT).

h) Anjurkan ibu untuk kontrol hari senin tanggal 2 Mei 2016 karena obat tuberculosis hanya sampai tanggal 3 Mei 2016. (Ibu mengerti untuk kontrol ulang hari senin tanggal 2 Mei 2016).
Pengkajian III Senin 2 Mei 2016, pukul 11.20 WIB, tempat Poli Paru

\section{Data Subyektif}

Ibu mengatakan kontrol ulang karena obatnya hanya sampai tgl 3 Mei 2016. Keluhan: batuknya membaik, nafsu makan membaik dan ibu merasakan tidak nyaman daerah punggung. Pola nutrisi sudah dirubah yaitu makan sedikit-sedikit tapi sering dengan memperbanyak makanan yang mengandung karbohidrat dan protein. Pola kebiasaan: selalu menggunakan masker.

\section{Data Obyektif}

KU: baik, kesadaran: composmentis, TD: 110/80 mmHg, Nadi: 90x/menit, RR: 26x/menit, Suhu: 36,5 ㅇ, BB: $56 \mathrm{~kg}$. Leopold I TFU 3 jari di atas pusat, teraba bulat lunak yaitu bokong janin. Leopold II bagian kanan teraba kecil-kecil yaitu ekstremitas janin. Bagian kiri teraba tahanan memanjang yaitu punggung janin. Leopold III teraba bulat keras yaitu kepala janin. Leopold IV konvergen. DJJ 135x/menit.

\section{Assesment}

Ny.W umur 35 tahun G4P2A1 umur kehamilan 29 minggu 1 hari, janin tunggal hidup intra uteri preskep puki konvergen dengan Tuberculosis Paru.

\section{Planning}

a) Kolaborasi dengan dokter spesialis paru mengenai hasil pemeriksaan bahwa keadaan ibu dan janin baik di tandai dengan TTV dan DJJ dalam batas normal. (Ibu dan keluarga mengerti dengan hasil pemeriksaan dan merasa senang).

b) Kolaborasi dengan dokter spesialis paru jelaskan pada ibu dan keluarga obat tuberculosis sebanyak 2 blister untuk 2 minggu, cara minum sama seperti sebelumnya yaitu 4 kaplet sekali minum dalam sehari, sebaiknya diminum malam hari dengan jarak 2 jam sebelum maupun setelah minum tablet tambah darah. (Ibu dan keluarga paham untuk cara minum OAT 2 blister untuk 2 minggu).

c) Beritahu ibu bahwa rasa tidak nyaman pada punggung hal yang wajar karena kehamilan ibu sudah trimester ke-3 beban pada perut ibu semakin berat sehingga berpengaruh pada punggung ibu. (Ibu paham dan tidak khawatir mengenai keluhannya).

d) Anjurkan ibu untuk tetap melakukan ANC ke tenaga kesehatan untuk mengetahui 


perkembangan janinnya dan tetap
mengkonsumsi obat yang diberikan oleh bidan
yaitu tablet Fe dan vitamin B6. (Ibu bersedia
untuk melakukan ANC dan tetap
mengkonsumsi obat dari bidan).
e) Beritahu ibu untuk kontrol 2 minggu lagi atau
sebelum obatnya habis yaitu Sabtu tanggal 14
Mei 2016. (Ibu bersedia untuk datang lagi pada
Sabtu tanggal 14 Mei 2016).

Dari beberapa pengkajian di atas ditemukan beberapa masalah-masalah yang ditemui dalam penerapan Manajemen Asuhan Kebidanan dan kendala-kendala pada kasus Ny.W, kendala tersebut menyangkut kesenjangan antara teori dan praktik. Kesenjangan yang ditemukan dikelompokkan menurut tahap proses Manajemen Asuhan Kebidanan.

\section{Pengumpulan Data Data Subyektif}

Pada kasus Ny.W datang mengeluh batukbatuk tidak kunjung sembuh selama 3 minggu, tidak enak badan, nafsu makan menurun dan demam. Hal ini merupakan gejala klinis pasien TB yang sesuai dengan Depkes (2008) bahwa gejala utama pasien TB paru adalah batuk berdahak selama 2-3 minggu atau lebih, dahak bercampur darah, batuk darah, sesak nafas, badan lemas, nafsu makan menurun, berat badan menurun, malaise, berkeringat malam hari tanpa kegiatan fisik, dan demam meriang lebih dari satu bulan.

Riwayat kesehatan Ny.W dahulu tidak pernah menderita penyakit menular, menurun dan menahun, riwayat kesehatan sekarang ibu sedang menderita batuk-batuk, tidak enak badan, nafsu makan menurun dan demam, riwayat kesehatan keluarga ibu mengatakan suaminya menderita penyakit TBC baru beberapa bulan yang lalu. Pengkajian ini sesuai dengan Maesaroh (2009) yaitu saat melakukan anamnesa pasien dengan gejala TB Paru kemungkinan pasien dahulu belum atau pernah menderita penyakit tersebut, apabila belum pernah pasien tersebut adalah pasien baru namun apabila pernah menderita pasien tersebut masuk dalam kategori pasien kambuh. Pada riwayat kesehatan keluarga menjelaskan bahwa penularan banyak terjadi dirumah oleh anggota keluarga sendiri, dan Ny.W mengatakan bahwa suaminya memiliki penyakit TBC.

Pola nutrisi Ny.W sebelum hamil adalah makan 3x/hari porsi 1 piring dan minum 7-8 gelas/hari, dan selama hamil makan $2 x$ /hari porsi sedikit dan minum \pm 6 gelas/hari, hal ini pola nutrisi Ny.W mengalami penurunan nafsu makan. Penurunan nafsu makan merupakan salah satu gejala klinis dari penyakit TB (Depkes, 2008).

Pada kasus ini ibu mengatakan tinggal di tempat yang bersih, bangunan permanen, lantai rumah kramik dan terdapat jendela di setiap ruangan rumah, sehingga sinar matahari dapat masuk di setiap ruangan rumahnya. Hal ini bukan termasuk factor pencetus timbulnya penyakit tuberculosis, karena menurut Depkes (2008) penularan terjadi dalam ruangan, factor pencetusnya mulai dari ventilasi, masuknya sinar matahari ke ruangan dan lembab tidaknya ruangan mempengaruhi ketahanan percikan dahak. Maka dalam hal ini tidak ditemukan kesenjangan antara teori dan dilahan praktik.

\section{Data Obyektif}

Pada kasus Ny.W keadaan umumnya baik. Hal ini sesuai dengan Depkes, (2008) pasien TB paru kadang-kadang keadaannya baik, meskipun penyakitnya sudah lanjut. Akan tetapi, mungkin pasien jelas kelihatan sakit. la mungkin sangat kurus, dengan turunnya berat badan yang jelas. la mungkin tampak pucat atau tampak kemerahan akibat demam.

Pemeriksaan tanda-tanda vital, nadi Ny.W 94x/menit, hal ini berbeda dengan Somantri (2007) pada pasien TB Paru pada pemeriksaan nadi umumnya meningkat seiring dengan demam. Meskipun disini terjadi perbedaan namun hal ini tidak berpengaruh besar terhadap kasus Ny.W.

Pemeriksaan pernafasan Ny.W 28x/menit, hal ini sesuai Somantri (2007) pada pasien TB Paru pada pemeriksaan pernafasan pada umumnya frekuensi pernafasan lebih cepat dikarenakan ada infeksi di paru-paru. Frekuensi pernapasan normalnya adalah 16-24x/menit (Astuti, 2012).

Suhu Ny.W $37,2^{\circ} \mathrm{C}$. Menurut Somantri (2007) pada kasus Tuberculosis paru pasien akan mengalami demam ringan yang biasanya terjadi pada siang hari. Dalam keadaan normal suhu badan berkisar 36,5-37,2으 (Astuti, 2012).

Berat badan Ny.W saat hamil adalah $56 \mathrm{~kg}$ dan berat badan sebelum hamil $49 \mathrm{~kg}$. Pada pengkajian ini menggunakan cara untuk menentukan berat badan menurut tinggi badan dengan menggunakan indeks massa tubuh (IMT) 
dengan rumus berat badan $(\mathrm{kg})$ dibagi tinggi badan (meter) pangkat 2 (Sulistyawati, 2009).

Berikut adalah cara untuk menentukan berat badan sesuai dengan tinggi badan dengan menggunakan indeks massa tubuh di lahan:

- Berat badan Ny.W sebelum hamil 49kg

- Tinggi badan Ny.W $155 \mathrm{~cm}=1,55 \mathrm{~m}$

Maka IMT Ny.W adalah 49/(1,55)』^2=20,3

Dari hasil menunjukkan IMT Ny.W termasuk kategori normal, untuk penambahan berat badan selama kehamilan berdasarkan IMT adalah 11,5$16 \mathrm{~kg}$. Namun dilahan penambahan berat badan Ny.W adalah $7 \mathrm{~kg}$, maka penambahan berat badan ibu hamil pada kasus Ny.W tidak sesuai dengan IMT.

Pemeriksaan lingkar lengan atas Ny.W adalah $23 \mathrm{~cm}$. Hal ini sesuai dengan Manuaba (2007) apabila lila $<23,5 \mathrm{~cm}$ merupakan indikator kuat untuk status gizi yang kurang/buruk. Status gizi yang kurang mengakibatkan ibu hamil dengan TB Paru mengalami kekurangan energy kronik (KEK) dan berat badan menurun (Depkes, 2008). Serta dapat mengakibatkan bayi lahir dengan berat badan rendah, sedangkan normal lila $\geq 23,5 \mathrm{~cm}$ (Manuaba, 2007).

Pemeriksaan dada Ny.W terdapat penarikan retraksi dinding dada, dan ada ronkhi. Tanda fisik ini sesuai dengan (Somantri, 2007) pada pasien TB Paru biasa ditemukan retraksi interkostal pada dada, pada pemeriksaan auskultasi mendengar ada tidaknya ronkhi basah, kasar dan nyaring, pemeriksaan perkusi untuk mengetahui ada tidaknya hipersonor/timpani dan suara pekak.

Pada ekstremitas Ny.W tidak oedem dan tidak varises baik pada ekstremitas atas dan bawah serta kanan maupun kiri. Hal ini berbeda dengan Crofton, dkk (2005) pada pasien TB Paru akan ditemukan jari-jari tabuh, tanda fisik ini akan ditemukan khususnya pada pasien dengan penyakit yang luas, yaitu pasien yang menderita penyakit TB dalam jangka waktu yang lama hingga terjadi tuberculosis ekstra paru, atau komplikasi lainnya. Meskipun terdapat perbedaan antara teori dan praktik hal ini tidak berpengaruh besar terhadap kasus, karena Ny.W adalah pasien baru yang menderita gejala awal TB Paru selama 3 minggu.

Pemeriksaan Penunjang Ny.W yaitu pemeriksaan dahak SPS (sewaktu pagi sewaktu) dan pemeriksaan radiologis. Hal ini sesuai Depkes,
(2008) diagnosis TB Paru ditegakkan dengan ditemukannya kuman TB (BTA). Pada program nasional, penemuan BTA melalui pemeriksaan dahak mikroskopik merupakan diagnosis utama. Pemeriksaan lain seperti foto toraks, biakan dan uji kepekaan dapat digunakan sebagai penunjang diagnosis sepanjang sesuai dengan indikasinya.

Pemeriksaan dahak mikroskopis berfungsi untuk menegakkan diagnosis, menilai keberhasilan pengobatan dan menentukan potensi penularan. Pemeriksaan biakan untuk mengetahui apakah pasien yang bersangkutan masih peka terhadap OAT yang digunakan. Selama fasilitas memungkinkan, biakan dan identifikasi kuman serta tes resistensi dapat dimanfaatkan dalam beberapa situasi yaitu pasien TB yang masuk dalam tipe pasien kronis, pasien TB ekstraparu, pasien TB anak, dan petugas kesehatan yang menangani pasien dengan kekebalan ganda (Depkes, 2008). Sehingga pada kasus Ny.W tidak dilakukan pemeriksaan biakan dan uji kepekaan karena Ny.W adalah pasien baru yang belum pernah mendapat terapi OAT.

\section{Interpretasi Data}

Diagnosa kebidanan pada Ny. W umur 35 tahun G4 P2 A1 usia kehamilan 28 minggu janin tunggal hidup intra uteri pungung kiri presentasi kepala konvergen dengan Tuberculosis Paru, yang memiliki dasar dari data subyektif ibu hamil dengan TB paru didapatkan anamnesa usia ibu 35 tahun dan mengeluh batuk-batuk 3 minggu, tidak enak badan, nafsu makan menurun dan demam, dan data obyektif yaitu ibu tampak sedikit pucat, lila $23 \mathrm{~cm}, \mathrm{RR} 28 \mathrm{x} /$ menit, suhu $37,2{ }^{\circ} \mathrm{C}$ dan pada pemeriksaan dada terdapat retraksi dinding dada serta terdapat bunyi ronkhi.

Pada diagnosa masalah kasus yang muncul yaitu ibu mengatakan merasa cemas dengan kondisi kehamilannya dengan keadaan tubuhnya yang batuk terus menerus, tidak enak badan, nafsu makan menurun disertai demam.

Kebutuhan yang diberikan kepada ibu yaitu memberikan informasi tentang tuberculosis, cara pengobatan, pencegahan dan beri motivasi kepada ibu terkait dengan kondisinya.

Pada langkah ini dilakukan identifikasi data secara benar terhadap diagnosis atau masalah kebutuhan pasien. Masalah atau diagnosis yang spesifik dapat ditemukan berdasarkan interpretasi yang benar terhadap dasar. Selain itu, sudah 
terpikirkan perencanaan yang dibutuhkan terhadap masalah (Wildan and Hidayat, 2008).

Pada langkah ini sesuai dengan standar Nomenklatur Diagnosa Kebidanan yaitu:

a. Diakui dan telah disyahkan oleh profesi

b. Berhubungan langsung dengan praktis kebidanan

c. Memiliki ciri khas kebidanan

d. Didukung oleh clinical judgment dalam praktik kebidanan

e. Dapat diselesaikan dengan pendekatan manajemen kebidanan (Muslihatun, Wafi N, 2009).

Menurut Kepmenkes RI No. 369/ MENKES/ PER/ 2010 tentang Standar Profesi Bidan kompetensi ketiga yaitu bidan memberi asuhan antenatal bermutu tinggi untuk mengoptimalkan kesehatan selama kehamilan yang meliputi: deteksi dini, pengobatan atau rujuk dan komplikasi tertentu.

Berdasarkan profesi bidan yang memiliki 3 tugas yaitu fungsi bidan menetapkan manajemen kebidanan pada setiap asuhan kebidanan yang diberikan, fungsi kolaborasi menerapkan manajemen kebidanan pada setiap asuhan kebidanan sesuai fungsi kolaborasi dengan melibatkan klien dan keluarga, memberikan asuhan kebidanan pada ibu hamil resiko tinggi dan pertolongan pertama kegawatan yang memerlukan tindakan kolaborasi (Mufdilah, 2012).

Pada kasus Ny. W di rumah sakit bidan sebagai pelaksana dalam melakukan asuhan kebidanan yang berkolaborasi dengan dokter spesialis kandungan dan dokter spesialis paru dalam menangani ibu hamil dengan TB Paru.

\section{Identifikasi Diagnosa}

Pada pengkajian ditemukan diagnose potensilanya adalah Tuberculosis Ekstra Paru, prematuritas, Intrauterine Growth Retardation (IUGR), dan berat badan lahir rendah. Hal ini sesuai dengan Prawirohardjo, (2009) bahwa diagnosa potensial yang dapat timbul pada kasus TB paru yaitu Tuberculosis Ekstra Paru, prematuritas, Intrauterine Growth Retardation (IUGR), dan berat badan lahir rendah serta kematian perinatal.

\section{Kebutuhan Tindakan Segera}

Dengan diagnosa potensial yang bisa saja muncul maka perlu dilakukan tindakan segera pada ibu hamil (Rukiyah, 2010). Pada kasus Ny.W dibutuhkan kolaborasi dengan dokter spesialis kandungan dan dokter spesialis paru, untuk tindakan pemeriksaan dahak oleh laboratorium dan pemeriksaan rontgen oleh radiologi. Pada langkah ini tidak ditemukan kesenjangan antara teori dan lahan dipraktik.

\section{Rencana Asuhan}

Menurut teori pada kasus ibu hamil dengan TB paru dilakukan perencanaan sebagai berikut:

1) Ibu diberikan 4 regimen kombinasi isoniazid, rifampisin, etambutol, dan pirazinamid selama 6 bulan. Pada 2 bulan pertama pengobatan adalah tahap intensif/ awal dan 4 bulan berikutnya adalah tahap lanjutan (Prawirohardjo, 2009).

2) Ibu diberikan pendidikan kesehatan mengenai nutrisi yang dibutuhkan pada ibu hamil dengan TB paru yaitu diet tinggi energy tinggi protein I yaitu energy sebanyak $2600 \mathrm{kkal}$ dan protein $100 \mathrm{gr}(2 / \mathrm{kg} \mathrm{BB})$ atau bisa juga diberikan diet tinggi energy tinggi protein II yaitu energy sebanyak $3000 \mathrm{kkal}$ dan protein 1225 gr (2,5 $\mathrm{gr} / \mathrm{kg} \mathrm{BB}$ ) (Nainggolan et al., 2012).

3) Ibu diberikan pendidikan kesehatan mengenai pencegahan penyakit TBC ke lingkungan sekitar diantaranya adalah dengan menggunakan masker, saat meludah jangan di tempat yang mudah tertularkan ke orang lain, jangan menggunakan barang atau alat bekas pakai oleh penderita TBC aktif ke orang lain dan melakukan pengobatan rutin di tenaga kesehatan (Andareto, 2015).

4) Ibu dianjurkan untuk sering melakukan antenatal care setiap dua minggu sekali, tujuannya untuk memantau pengobatan OAT dan mendeteksi komplikasi lainnya (Fraser, 2009).

Berdasarkan perencanaan dilahan dan teori terdapat perbedaan, yaitu dilahan tidak diberikan perencanaan mengenai diet tinggi energy tinggi protein I yaitu energy sebanyak $2600 \mathrm{kkal}$ dan protein $100 \mathrm{gr}(2 / \mathrm{kg} \mathrm{BB})$ atau diet tinggi energy tinggi protein II yaitu energy sebanyak 3000 kkal dan protein $1225 \mathrm{gr}(2,5 \mathrm{gr} / \mathrm{kg} \mathrm{BB})$ sesuai dengan penelitian (Nainggolan et al., 2012).

\section{Pelaksanaan Asuhan}

Pada langkah keenam ini, pelaksanaan asuhan menyeluruh seperti yang telah diuraikan pada langkah kelima dilaksanakan secara efisien dan aman. Dalam hal ini terdapat kesenjangan antara teori dan dilahan sesuai dengan langkah sebelumnya, yaitu dilahan tidak memberikan 
pelaksanaan mengenai diet tinggi energy tinggi protein I atau diet tinggi energy tinggi protein II.

\section{Evaluasi}

Pada kasus Ny. W dengan hamil TB Paru diperoleh evaluasi yaitu batuk-batuk yang diderita ibu sudah mulai berkurang, setelah dilakukan 3 kali pengkajian didapatkan hasil ibu yaitu ibu sudah mengerti keadaan nya sehingga ibu sudah tidak merasa cemas lagi, ibu sudah mengetahui pola makan dan penyebab penularan penyakit TB, terapi sudah diberikan yaitu dengan obat anti tuberculosis dan pada pengkajian ketiga batuknya membaik dan nafsu makan sudah membaik, ibu bersedia untuk tetap melakukan antenatal care di tenaga kesehatan, ibu bersedia minum OAT setiap hari serta ibu bersedia kontrol ulang ke Rumah Sakit atas anjuran dokter spesialis paru.

Langkah ini sesuai dengan teori yaitu dilakukan evaluasi keefektifan dari asuhan yang sudah diberikan meliputi pemenuhan kebutuhan akan bantuan apakah benar-benar telah terpenuhi sesuai dengan kebutuhan sebagaimana telah diidentifikasikan di dalam masalah dan diagnose. Rencana tersebut dapat dianggap efektif jika memang benar efektif dalam penatalaksanaannya (Mufdilah, 2012).

Pada langkah ini tidak ditemukan adanya kesenjangan antara teori dan kasus yang ada dilahan praktek karena pemenuhan kebutuhan akan bantuan tenaga kesehatan sudah terpenuhi dengan baik sesuai dengan kebutuhan sebagaimana yang telah diidentifikasi dalam masalah dan diagnosa.

\section{Simpulan}

Pelaksanaan Asuhan Kebidanan pada ibu hamil dengan Tuberculosis Paru di RSUD Dr. Adyatma, MPH Semarang dapat diambil kesimpulan sebagai berikut:

Setelah mendapatkan penanganan yang baik dari tanggal 26 April 2016 sampai 2 Mei 2016 hasil dari tindakan sudah teratasi dengan baik, terbukti saat pertama kali datang Ny. W dengan keluhan batuk-batuk tidak kunjung sembuh selama 3 minggu, tidak enak badan, nafsu makan menurun dan demam pada pengkajian ketiga Ny. W mengatakan batuknya membaik daripada minggu lalu, nafsu makan sudah membaik. Kondisi Ny. W membaik tidak merasakan cemas lagi dan tidak terdapat hal-hal yang mengarah pada komplikasi sehingga ibu dapat menjalani kehamilan dengan normal.

Penerapan asuhan kebidanan pada Ny. W dengan Tuberculosis Paru telah sesuai yang didasarkan pada tujuh Langkah Varney yang terdiri dari pengumpulan data, interpretasi data, identifikasi diagnose atau masalah potensial, kebutuhan tindakan segera, rencana asuhan, pelaksanaan asuhan dan evaluasi. Semua Langkah ini dilakukan dengan tepat sesuai kebutuhan pasien sehingga masalah dapat diatasi.

ditemukan adanya kesenjangan antara praktik dilahan dan teori dalam melakukan asuhan kebidanan, kesenjangan yang ditemukan dikelompokan sesuai dengan tujuh Langkah Manajemen Asuhan Kebidanan.

\section{Ucapan terima kasih}

Ucapan terimakasih diberikan kepada seluruh pihak-pihak instansi RSUD Dr. Adyatma, MPH Semarang dan Dinas Kesehatan yang berkontribusi dalam penyusunan dan penyelesaian penelitian ini.

\section{Daftar Pustaka}

Andareto, O. (2015) Penyakit Menular di Sekitar Anda. Jakarta: Pustaka IImu Semesta.

Astuti, H. P. (2012) Buku Ajar Asuhan Kebidanan Ibu 1 Kehamilan. Yogyakarta: Rohima Press.

Crofton, John, N. H. dan F. M. (2005) Tuberkulosis Klinis. 2nd edn. Jakarta: Widya Medika.

Depkes, R. (2008) Pedoman Nasional Penanggulangan Tuberkulosis. 2nd edn. Jakarta: Bakti Husada.

Dinas Kesehatan Provinsi Jawa Tengah (2015) 'Profil Dinas Kesehatan Provinsi Jawa Tengah Tahun 2015', 3511351(24). Available at: https://www.kemkes.go.id/resources/downl oad/profil/PROFIL_KES_PROVINSI_2015/13_ Jateng_2015.pdf.

Fraser, D. M. dan M. A. C. (2009) Buku Ajar Bidan. Edisi 14. Jakarta: EGC. 
Maesaroh, S. (2009) Faktor-faktor yang Berhubungan Dengan Kepatuhan Berobat Pasien Tuberkulosis Paru Di Klinik Jakarta Respiratory Centre (JRC)/ PPTI Tahun 2009. Universitas Islam Negeri Syarif Hidayatullah Jakarta. Available at: http://repository.uinjkt.ac.id/dspace/bitstre am/123456789/25866/1/SITI MAESAROHFKIK.pdf.

Manuaba, I. (2007) Pengantar Kuliah Obstetri. Jakarta: EGC.

Marmi, D. (2011) Asuhan Kebidanan Patologi. Yogyakarta: Pustaka Pelajar.

Mufdilah, D. (2012) Konsep Kebidanan Edisi Revisi. Yogyakarta: Nuha Medika.

Muslihatun, Wafi N, D. (2009) Dokumentasi Kebidanan. Yogyakarta: Fitramaya.

Nainggolan et al. (2012) 'Analisis Diet Tinggi Kalori Tinggi Protein (TKTP) pada Penderita TB Paru Rawat Inap di Rumah Sakit Martha Friska Pulo Brayan Tahun 2012', Repositori Institusi USU. Available at: http://download.garuda.ristekdikti.go.id/arti cle.php?article $=1424542 \&$ val $=4108 \&$ title $=A$
NALISIS DIET TINGGI KALORI TINGGI PROTEIN TKTP PADA PENDERITA TB PARU RAWAT INAP DI RUMAH SAKIT MARTHA FRISKA PULO BRAYAN TAHUN 2012.

Prawirohardjo, S. (2009) Ilmu Kebidanan. Jakarta: Bina Pustaka Sarwono Prawirohardjo.

Rukiyah, A. Y. dan L. Y. (2010) Asuhan Kebidanan 4 Patologi Kebidanan. Jakarta: CV Trans Info Media.

Somantri, I. (2007) Keperawatan Medikal Bedah: Asuhan Keperawatan pada Pasien dengan Gangguan Sistem Pernapasan. Jakarta: Salemba Medika.

Sulistyawati, A. (2009) Asuhan Kebidanan pada Masa Kehamilan. Jakarta: Salemba Medika.

Varney, H. (2007) Buku Ajar Asuhan Kebidanan. Edited by W. E. Ana Lusiyana, Laily Mahmudah, Gita Trisetyati. Jakarta: EGC.

Wildan, M. and Hidayat, A. A. A. (2008) Dokumentasi Kebidanan. Jakarta: Penerbit Salemba Medika. 